\title{
Effects of exogenous oxytocin and progesterone on GnRH-induced short luteal phases in anoestrous ewes
}

\author{
A. P. Beard and M. G. Hunter* \\ Department of Physiology and Environmental Science, Faculty of Agricultural and Food Sciences, \\ University of Nottingham, Sutton Bonington Campus, Leics LE12 5RD, UK
}

\begin{abstract}
Two experiments investigate the effects of oxytocin and progesterone on premature luteolysis in ewes. In Expt 1, 20 anoestrous ewes were induced to ovulate by multiple injections of $\mathrm{GnRH}(250 \mathrm{ng}$ i.v. every $2 \mathrm{~h}$ for $24 \mathrm{~h}$ ) followed by a bolus injection of GnRH (125 $\mu \mathrm{g}$, i.v.). Ten ewes received a continuous infusion of oxytocin from the day after the $\mathrm{GnRH}$ bolus injection and the other ten ewes were infused with saline. Oxytocin infusion had no significant effect on the proportion of ewes with short luteal phases $(P>0.05)$. All ewes that had luteal phases of normal duration from either group $(n=9)$ exhibited a transient increase in plasma concentrations of progesterone $2 \mathrm{~h}$ after insertion of the pump. In Expt 2, 25 anoestrous ewes were treated with GnRH as in Expt 1. Five ewes were pretreated with progestagen for 11 days and ten ewes received progesterone ( $12 \mathrm{mg}$, i.m.) $24 \mathrm{~h}$ after the bolus injection of $\mathrm{GnRH}$. All animals received an oxytocin injection ( $1 \mu \mathrm{g}$, i.v.) on day 4 after the GnRH bolus. All five ewes that were pretreated with progestagen had normal luteal function and none exhibited a 13,14-dihydro-15-keto PGF $_{2 \alpha}$ (PGFM) response to oxytocin. None of the ten ewes injected with progesterone had a normal luteal phase and six ewes exhibited a PGFM response to oxytocin. Four ewes in the control group had normal luteal function and three had short luteal phases. It is concluded that (I) administration of oxytocin from about the time of ovulation does not prevent premature luteal regression; (2) a transient increase in progesterone at about the time of ovulation is associated with luteal phases of normal duration; (3) a more extended exposure to progesterone at about the time of ovulation prevents normal luteal function and may inhibit luteinization and (4) pretreatment with progesterone prevents luteolysis by reducing the uterine response to oxytocin early in the luteal phase.
\end{abstract}

\section{Introduction}

Seasonally anoestrous ewes induced to ovulate with multiple injections of $\mathrm{GnRH}$, without prior treatment with progesterone, frequently form a corpus luteum that undergoes premature regression 4 days later (Southee et al., 1988a). These corpora lutea with a short lifespan provide a suitable model for the study of premature luteolysis which often occurs after the first ovulation following a period of ovarian quiescence (for example, at puberty, or the transition from seasonal or lactational anoestrus) (Yuthasastrakosol et al., 1975; Lamming et al., 1981).

The premature regression of the $\mathrm{GnRH}$-induced corpus luteum has been shown to be a result of the precocious activation of the normal luteolytic mechanism, involving the coincident secretion of oxytocin from the corpus luteum and $\mathrm{PGF}_{2 a}$ from the uterus (Hunter et al., 1989; Hunter, 1991). As in the control of luteolysis at the end of a normal luteal phase, oxytocin receptors play a pivotal role in the initiation of

\footnotetext{
*Reprint requests.
}

Received 19 July 1995. premature luteolysis. Ewes which exhibit abnormal luteal function have higher concentrations of uterine oxytocin receptors present 5 days after $\mathrm{GnRH}$ treatment than do ewes displaying normal luteal function (Hunter et al., 1989). Pretreatment with progesterone before $\mathrm{GnRH}$ therapy prevents premature luteolysis. Ewes, pretreated with progesterone, have similar numbers of oxytocin receptors at oestrus as ewes not pretreated with progesterone. The increased numbers of receptors on day 5 in ewes not pretreated appear to result from a slower decline in receptor concentration during the early luteal phase compared with the decline in ewes pretreated with progesterone (Hunter, 1991; Beard and Hunter, 1994a). Progesterone has a negative influence on oxytocin receptors during the luteal phase and in steroid hormone treated, ovariectomized ewes (Homanics and Silvia, 1988; Lau et al., 1992; Beard ef al., 1994).

Flint and Sheldrick (1985) showed that continuous infusion of oxytocin in ewes from day 13 to day 21 of the oestrous cycle delayed the return to oestrus by 7 days, by inhibiting the production of uterine $\mathrm{PGF}_{2 \alpha}$ by downregulating the uterine oxytocin receptor (Sheldrick and Flint, 1990). It is not known 
whether oxytocin can block premature luteolysis in a similar manner.

The aims of the present study were to investigate whether premature luteolysis in anoestrous ewes induced to ovulate by GnRH treatment could be prevented either by a continuous infusion of oxytocin beginning $24 \mathrm{~h}$ after the final $\mathrm{GnRH}$ treatment or by a single injection of progesterone administered around the time of ovulation. In the latter experiment, an oxytocin challenge was also used to investigate the role of functional oxytocin receptors.

\section{Materials and Methods}

\section{Animals}

Mature, Romney Marsh ewes $(n=45)$ were housed under natural conditions of daylength and temperature and both experiments were performed during April-July.

\section{Treatment and blood sampling}

Experiment 1. All animals $(n=20)$ were given $250 \mathrm{ng}$ GnRH i.v. (Lutal: Fabwerke Hoechst AG, Frankfurt) in $2 \mathrm{ml}$ sterile saline every $2 \mathrm{~h}$ for $24 \mathrm{~h}$, followed by a bolus injection of $125 \mu \mathrm{g} \mathrm{GnRH}$ i.v., a regimen known to synchronize the time of the LH surge (Hunter et al., 1988; Beard and Hunter, 1994b). Time zero was the time of the bolus GnRH injection. Ten ewes (oxytocin-treated group) were implanted with an osmotic mini pump (Alzet, Model 2ML1: Alza Corp., Palo Alto, CA; flow rate $\left.=2.08 \mu \mathrm{l} \mathrm{h}^{-1}\right)$ filled with oxytocin $\left(1.5 \mathrm{mg} \mathrm{ml}{ }^{-1}\right)$ (Fabwerke Hoechst) diluted in saline plus $0.01 \%(\mathrm{v} / \mathrm{v})$ acetic acid, $24 \mathrm{~h}$ after the bolus GnRH injection. The other ten ewes (control group) were implanted with osmotic pumps filled with saline plus $0.01 \%(\mathrm{v} / \mathrm{v})$ acetic acid. The prefilled pumps were incubated in saline at $37^{\circ} \mathrm{C}$ overnight and then inserted via a $3 \mathrm{~cm}$ incision in the axilla region under local anaesthetic $(5 \mathrm{ml}$, Lignavet Plus: C-Vet Ltd, Bury St Edmunds, Suffolk). The jugular vein of all ewes was cannulated 2 days before the GnRH bolus injection. Blood samples for assay of progesterone $(5 \mathrm{ml})$ and oxytocin $(7 \mathrm{ml})$ were taken every $12 \mathrm{~h}$ from the beginning of GnRH treatment and then daily from day 6 until death (12 or 13 days after insertion of the pump). A further sample was also taken $2 \mathrm{~h}$ after insertion of the pump. Samples for analysis of oxytocin and 13,14-dihydro-14-keto-PGF ${ }_{2 a}$ (PGFM) were taken at intervals of $1 \mathrm{~h}$ for periods of $12 \mathrm{~h}$ on days 4 and 5 after the GnRH bolus injection.

Experiment 2. All animals $(n=25)$ were given $\mathrm{GnRH}$ as described for Expt 1. The control group $(n=10)$ received no other treatment. The progesterone pretreatment group $(n=5)$ were pretreated with an intravaginal progestagen (fluorogestone acetate) sponge for 11 days and the third group received an i.m. injection of progesterone ( $1 \mathrm{ml} 12 \mathrm{mg} \mathrm{ml}^{-1}$, in $90 \%$ corn oil) $24 \mathrm{~h}$ after the bolus injection of $\mathrm{GnRH}$ (progesteroneinjected group, $n=10$ ). Time zero was the time of the bolus $\mathrm{GnRH}$ injection. All groups received an oxytocin injection ( $1 \mathrm{ml}$ of $1 \mu \mathrm{g}$ oxytocin $\mathrm{ml}^{-1}$ in saline, i.v.) on day 4 . The jugular veins of all ewes were cannulated 6 days before the bolus injection of $\mathrm{GnRH}$. Samples for progesterone assay ( $5 \mathrm{ml}$ ) were collected once a day from day 6 to day 1 , every hour on day 1 , twice a day from days $2-4$, once a day on days $5-7$, and then on alternate days until death (day 15). Plasma samples $(5 \mathrm{ml})$ were collected for assay of PGFM at 20 min intervals in the hour before the oxytocin injection and at $10 \mathrm{~min}$ intervals in the following hour (post-treatment period).

\section{Radioimmunoassays}

Samples were assayed for progesterone as described by Hunter et al. (1986). In Expts 1 and 2, the mean extraction efficiencies were $81 \%$ and $81 \%$; the limits of sensitivity were 0.13 and $0.18 \mathrm{ng} \mathrm{ml}^{-1}$; and the intra- and interassay coefficients of variation were $9.5,10.3$ and $11.7,11.9 \%$, respectively.

Plasma concentrations of PGFM were measured as described by Kaker et al. (1984). In Expts 1 and 2, the mean extraction efficiencies were 88 and $85 \%$, the limits of sensitivity were 27 and $34 \mathrm{pg} \mathrm{ml}^{-1}$ and intra- and interassay coefficients of variation were $16,13.4$ and $20.2,19.4 \%$, respectively.

Plasma concentrations of oxytocin were measured in a single assay as described by Wathes et al. (1986) and the limit of sensitivity was $0.5 \mathrm{pg} \mathrm{ml}^{-1}$ and the intra-assay coefficient of variation was $19 \%$.

\section{Statistical analyses}

Ewes were classified as displaying either normal or abnormal luteal function using progesterone profiles and gross examination of the ovaries. Normal luteal function resulted in an increase in progesterone concentrations from day 2 to reach a concentration $>1 \mathrm{ng} \mathrm{ml}^{-1}$ by day 6 . Abnormal luteal function was defined as a transient rise in plasma concentrations of progesterone above baseline values to $>0.3 \mathrm{ng} \mathrm{ml}^{-1}$ by day 3 followed by a decline to basal values by day 5 (Southee $e t$ al., 1988a; Beard and Hunter, 1994b). The effects of treatment on the frequency of normal/abnormal luteal function in both experiments were tested by chi-squared analysis. The effects of treatments on the progesterone profiles (area under the curve) and on masses of corpora lutea (Expt 1) were examined by Student's $t$ test.

The PGFM data in Expt 2 were examined by ANOVA, the residuals were normally distributed and the magnitude of the residuals remained approximately constant over the range of values recorded. Effects of treatment on the post-treatment PGFM concentration were determined by split-spot ANOVA with individual sheep used as plots and samples as subplots. Differences in group means were evaluated by orthogonal contrasts (Lowry, 1992) (the control group was divided into two subgroups of ewes displaying abnormal and normal luteal function). A PGFM response was defined as an increase in at least two points during the post-treatment period that exceeded the pretreatment mean $+2 \mathrm{sD}$.

\section{Results}

\section{Experiment 1}

Ovarian activity. Two animals, one in each group, had high progesterone profiles at the start of $\mathrm{GnRH}$ treatment and a 


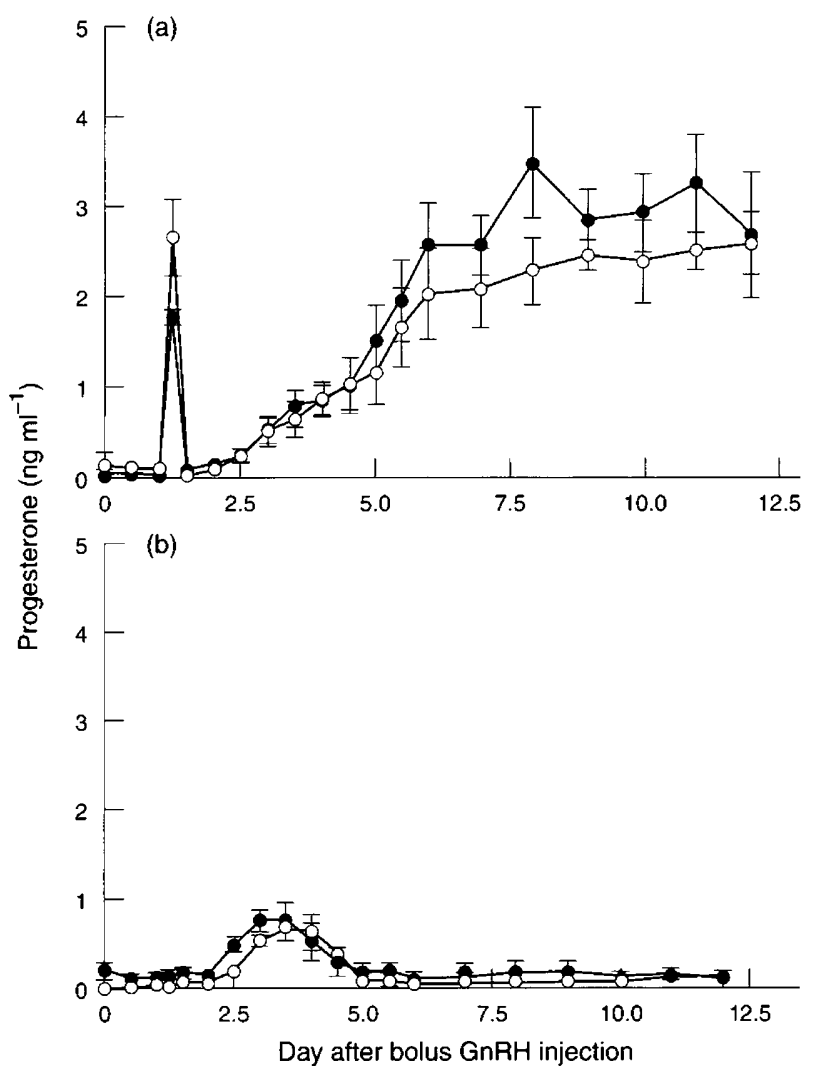

Fig. 1. Plasma progesterone profiles (mean \pm SEM) of anoestrous ewes induced to ovulate with multiple injections of $\mathrm{GnRH}$ (250 ng i.v. every $2 \mathrm{~h}$ for $24 \mathrm{~h}$ ) followed by a bolus injection of GnRH (125 $\mu \mathrm{g}$, i.v.). Oxytocin-treated animals (O) received a continuous infusion of oxytocin from the day after the GnRH bolus injection and control animals (•) were infused with saline. (a) Normal luteal function in control $(n=4)$ and oxytocin-treated ( $n=5)$ groups. (b) Short luteal phases in the control $(n=3)$ and oxytocin-treated $(n=3)$ groups. Time 0 is the time of the $\mathrm{GnRH}$ bolus injection.

further three ewes (two control, one oxytocin-treated) failed to form corpora lutea, and, thus, had no increase in progesterone concentrations above basal values. All these ewes were excluded from further study. All other ewes ovulated and their progesterone profiles are described below. Oxytocin treatment had no effect on ovulation rate $(2.3 \pm 0.3$ and $2.5 \pm 0.5$ for control and oxytocin-treated, respectively; $P>0.05$ ) or mass of corpus luteum $(426 \pm 73$ and $389 \pm 62 \mathrm{mg}$ for control and oxytocin-treated, respectively; $P>0.05$ ) in animals with normal luteal function.

Progesterone profiles. The profiles of ewes with normal luteal function in the control $(n=4)$ and oxytocin-treated groups $(n=5)$, which were not different $(P>0.05)$, are shown (Fig. 1a). All ewes exhibited increased concentrations of plasma progesterone $2 \mathrm{~h}$ after insertion of the pump. Progesterone concentrations increased to a mean of $2.3 \pm 0.4 \mathrm{ng} \mathrm{ml}^{-1}$ from basal values measured $5 \mathrm{~h}$ previously and had declined to basal values $7 \mathrm{~h}$ later. The profiles of ewes displaying short luteal phases in the control $(n=3)$ and oxytocin-treated $(n=3)$ groups, the proportion of which did not differ between the groups $(P>0.05)$, are shown (Fig. Ib). In both groups, progesterone values had started to decline before day 5 . None of the ewes showed an increase in progesterone around the time of pump insertion.

Oxytocin profiles. In the oxytocin-treated animals, oxytocin concentrations had reached at least $20 \mathrm{pg} \mathrm{ml}^{-1} 24 \mathrm{~h}$ after insertion of the pump and remained continuously increased at between 20 and $35 \mathrm{pg} \mathrm{ml}^{-1}$ in all animals until slaughter. Oxytocin concentrations were measured in two ewes randomly selected from the control group and were below $10 \mathrm{pg} \mathrm{ml}^{-1}$ throughout the treatment period.

Frequent sampling. Sampling every hour revealed surges of oxytocin reaching $>20 \mathrm{pg} \mathrm{ml}^{-1}$ in two of the three ewes in the control group displaying short luteal phases. In both of these ewes there was a simultaneous release of PGFM. This coincident release pattern was not observed in any of the ewes with normal luteal phases (results not shown).

\section{Experiment 2}

Ovarian activity. All ewes in the progesterone-pretreated group had apparently normal corpora lutea, as did four ewes in the control group; the remaining three ewes failed to form corpora lutea and thus progesterone concentrations remained at basal values. The ovaries of one ewe in the progesteroneinjected group had only follicles. All other ewes had corpora albicantia $<0.01 \mathrm{~g}$, with the exception of one ewe in the progesterone-injected group which had a corpus albicans of $0.12 \mathrm{~g}$.

Progesterone profiles. Progesterone profiles indicate that all ewes in the progesterone-pretreated group displayed normal luteal function, as did four ewes in the control group (Fig. 2a). These profiles were not different between the groups $(P>0.05)$. Three ewes in the control group displayed a progesterone profile typical of a short luteal phase (Fig. 2b). The proportion of ewes exhibiting abnormal luteal function was greater in the control group than in the progesteronepretreated group $(P<0.05)$. No ewes in the progesteroneinjected group displayed normal luteal function (Fig. 3), and it is probable that all ewes in this group failed to form corpora lutea capable of secreting measurable amounts of progesterone. Progesterone concentrations increased rapidly to between 1.5 and $2.0 \mathrm{ng} \mathrm{ml}^{-1}$, and then declined exponentially; however, concentrations were still above basal values $72 \mathrm{~h}$ after progesterone administration. A transient increase on days 3 and 4 , indicative of the formation of a corpus luteum of short lifespan, was not evident.

PGFM. In the progesterone-pretreated group, no ewes exhibited a defined PGFM response to the administered oxytocin. In the control group, one ewe in each of the categories displaying normal or abnormal luteal function responded to oxytocin ( 25 and $33 \%$ of ewes, respectively), whereas six ewes in the progesterone-injected group demonstrated a defined response to oxytocin (60\% of ewes). The mean PGFM response pattern for each group is shown (Fig. 4). 


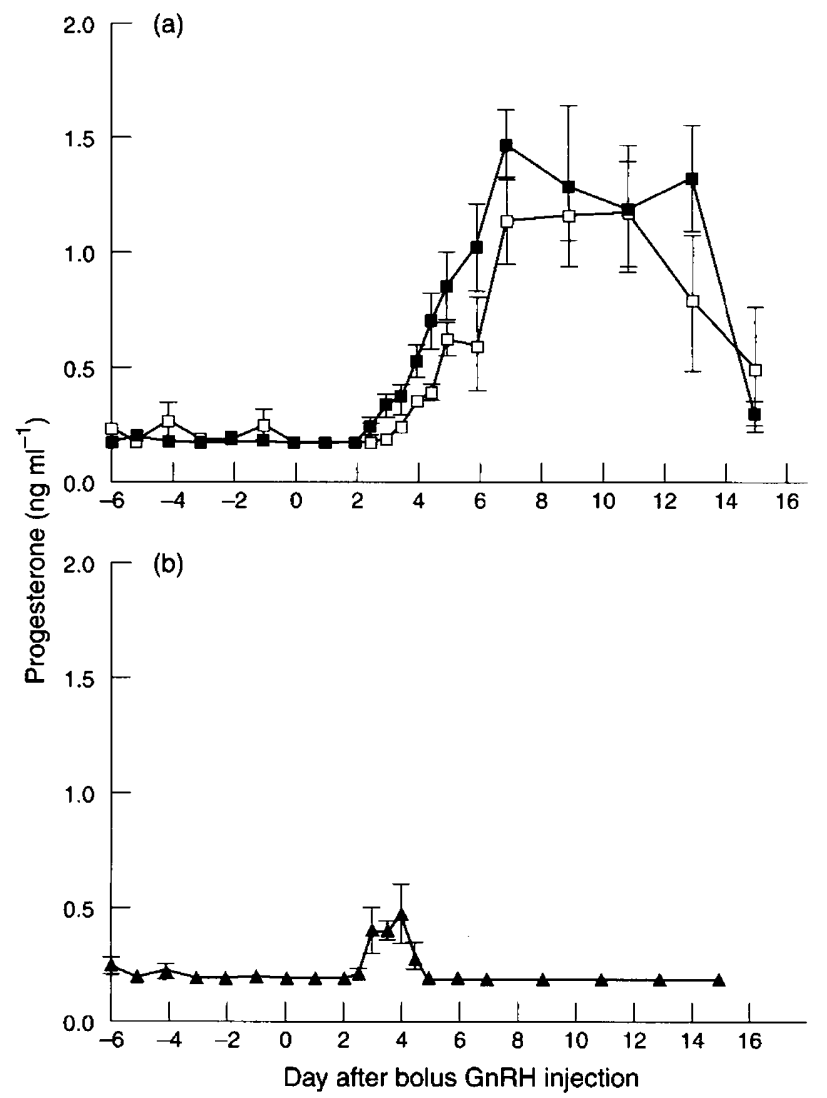

Fig. 2. Plasma progesterone profiles (mean \pm SEM) of anoestrous ewes induced to ovulate with multiple injections of $\mathrm{GnRH}$ ( $250 \mathrm{ng}$ i.v. every $2 \mathrm{~h}$ for $24 \mathrm{~h}$ ) followed by a bolus injection of GnRH (125 $\mu \mathrm{g}$, i.v.). One group was pretreated with progestagen for 11 days before GnRH administration; the control group received no other treatment. (a) Normal luteal function in the progesterone-pretreated $(\square ; n=3)$ and control $(\square ; n=4)$ groups and (b) short luteal phases in the control $(\Delta ; n=3)$ group. Time 0 is the time of the GnRH bolus injection.

There was an effect of treatment on mean PFGM concentrations following oxytocin administration $(P<0.05)$. Ewes pretreated with progesterone had lower concentrations of PGFM following oxytocin administration than did ewes not pretreated with progesterone $(P<0.05)$. Despite an apparent increase in the mean PGFM concentration, in response to oxytocin in the control, short-lifespan group, this was not significantly different to the concentration measured in the control, normal group. However, there was a large inter-animal variation within groups.

\section{Discussion}

Experiment 1 confirmed that the abnormal luteal function that occurs following GnRH therapy in some anoestrous ewes is characterized by a corpus luteum of short lifespan, producing only a transient increase in plasma progesterone concentrations (Southee et al., 1988a; Hunter, 1991; Beard and Hunter, 1994b). The proportion of corpora lutea having a short lifespan was not affected by continuous oxytocin infusion. This result may appear initially to contradict that obtained by Flint and

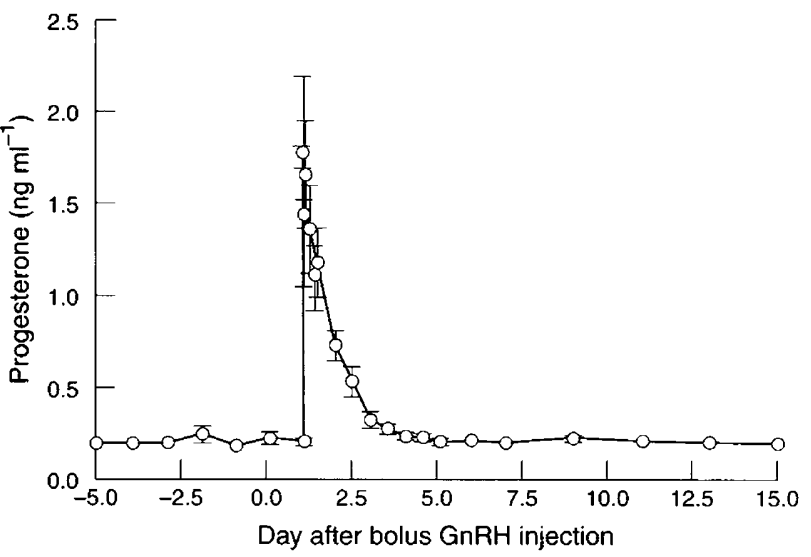

Fig. 3. Plasma progesterone profiles (mean \pm SEM) of ewes that had received multiple injections of $\mathrm{GnRH}$ ( $250 \mathrm{ng}$, i.v. every $2 \mathrm{~h}$ for $24 \mathrm{~h}$ ), followed by a bolus injection of GnRH ( $125 \mu \mathrm{g}$, i.v.) and then $12 \mathrm{mg}$ progesterone (i.m.) $24 \mathrm{~h}$ after the $\mathrm{GnRH}$ bolus $(n=10)$. Time 0 is the time of the GnRH bolus injection.

Sheldrick (1985) who showed that continuous infusion of a similar amount of oxytocin, beginning on day 13, blocked luteolysis and extended the luteal phase in cyclic ewes. They demonstrated that oxytocin treatment prevented the development of oxytocin receptors, which normally precedes oestrus, and thereby disrupted the functioning of the feedback loop linking the uterus and ovary that is vital to the luteolytic mechanism. In the present study, the premature regression occurred via the normal luteolytic mechanism since synchronous pulses of oxytocin and PGFM were detected. Thus, it appears that the oxytocin infusion was unable to downregulate the existing oxytocin receptors present when the infusion began on day 1 (Hunter, 1991). Sheldrick and Flint (1986) showed that administration of oxytocin to ewes with large numbers of uterine oxytocin receptors already present had no effect on numbers of receptors and this provides an explanation for the difference in the results obtained.

In Expt 1, the incidence of abnormal luteal function was lower in the control group of ewes than that reported by McLeod et al. (1982) and Southee et al. (1988a,b). It appears likely that this increase in the proportion of normal luteal phases is related to the short-lived discharge of progesterone that occurred at the time of pump insertion, since this release only occurred in ewes that subsequently had normal luteal phases. The temporarily increased progesterone concentrations may cause subsequent normal luteal function by decreasing the amount of functional oxytocin receptors in the uterus. The increase in plasma progesterone may have been due to a stress release of progesterone similar to that reported previously in fallow deer (Asher et al., 1989) and calves (Cooper et al., 1995). It is unknown whether the short increase in progesterone and the normal luteal function were the result of an unknown independent mechanism, or, whether the progesterone rise was the cause of subsequent normal luteal function. Expt 2 was designed to investigate this further.

The progesterone injection administered in Expt 2 was designed to simulate the rise measured in Expt 1. The release/metabolism of progesterone administered on day 1 was considerably slower than expected from previous work (Beard 

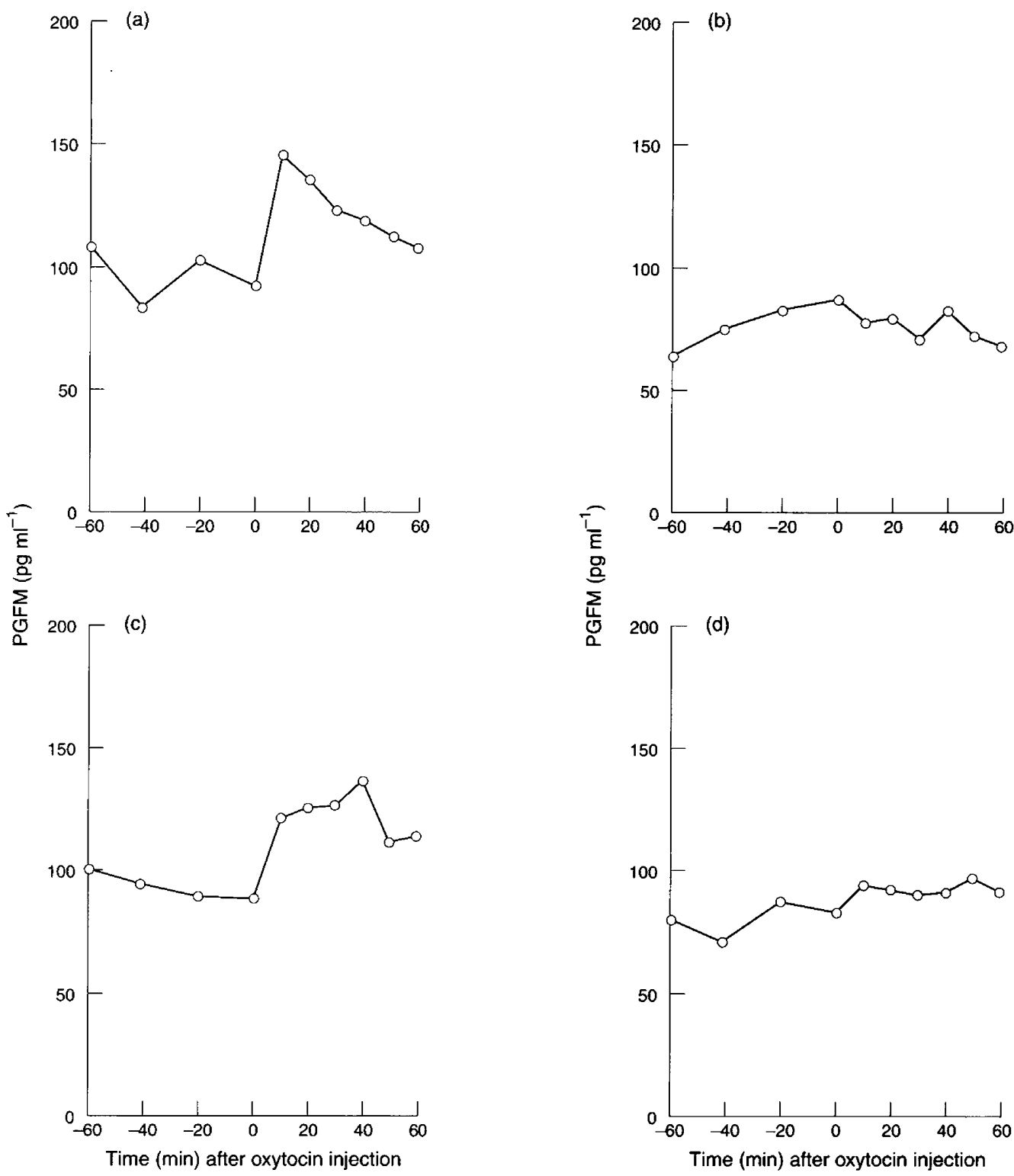

Fig. 4. Plasma 13,14-dihydro-15-keto $\mathrm{PGF}_{2 u}$ (PGFM) response profiles (means) of ewes that received multiple injections of GnRH ( $250 \mathrm{ng}$, i.v. every $2 \mathrm{~h}$ for $24 \mathrm{~h}$ ) followed by a bolus injection of GnRH ( $125 \mu \mathrm{g}$, i.v.). In addition to treatments detailed below, all groups received an injection of $1 \mu \mathrm{g}$ oxytocin in $1 \mathrm{ml}$ saline (i.v.) on day 4 after the bolus injection of GnRH. (a) Ewes received $12 \mathrm{mg}$ progesterone (i.m.) $24 \mathrm{~h}$ after the GnRH bolus $(n=10)$; (b) ewes were pretreated with progesterone for 11 days before $\mathrm{GnRH}$ treatment $(n=5)$; (c) control ewes that displayed short luteal phases $(n=3)$ and $(d)$ control ewes that displayed normal luteal function $(n=4)$. Time $O$ is the time of the oxytocin injection. SED $=31.1$.

and Hunter, 1994a), as progesterone concentrations were still above pretreatment concentrations $72 \mathrm{~h}$ after treatment. The reasons for the slower release/metabolism were not established, although differences in the site of injection, or release from the injection site may account for the differences between studies. The slow decline in progesterone concentrations following the injections made it difficult to determine whether any endogenous progesterone secretion had occurred. However, progesterone concentrations were basal on days 4 and 5, and the formation of corpora lutea of short lifespan is usually characterized by increased progesterone concentrations (to approximately $0.5 \mathrm{ng} \mathrm{ml}^{-1}$ ) at this time. It was, therefore, concluded that ewes treated with progesterone failed to form functional corpora lutea of any description, that is, neither normal, nor short lifespan corpora lutea were formed.

It was not possible to determine conclusively whether the lack of progesterone secretion in the progesterone-injected ewes was due to the disruption of ovulation or to luteinization. However, studies have shown that the bolus injection of $\mathrm{GnRH}$ (at time zero) immediately stimulates the LH surge (McLeod and Haresign, 1984), and this is thought to stimulate ovulation 21-26 h later (Cumming et al., 1973). Therefore, it is unlikely 
that the progesterone injection (administered $24 \mathrm{~h}$ after the $\mathrm{GnRH}$ bolus) inhibited ovulation, which may have already occurred in a number of ewes. It is proposed that the progesterone injection inhibited the normal luteinization mechanism in an unknown manner. In previous studies in sheep, progesterone administration early in the luteal phase allowed luteal function to continue as normal until luteolysis, which was induced a number of days early (Bray et al., 1976; Ottobre et al., 1980). A large single injection of progesterone administered to ewes on the day of oestrus, or on the following day, did not appear to inhibit luteinization (Dixon and Thwaites, 1973). Therefore, the inhibition of luteal development by progesterone treatment $24 \mathrm{~h}$ after the LH surge is a novel and unexpected observation.

In Expt 2, pretreatment with progesterone inhibited the premature regression of the induced corpus luteum. This study is the first to show that progesterone treatment inhibits the PGFM response to oxytocin administered to ewes at the time of premature luteolysis. This result supports the contention that premature luteolysis is the result of the precocious activation of the normal luteolytic mechanism involving the secretion of luteal oxytocin and uterine $\mathrm{PGF}_{2 \alpha}$. Furthermore, it indicates that pretreatment with progesterone prevents premature luteolysis by inactivating the luteolytic positive-feedback mechanism at the point of the uterine response to oxytocin. Progesterone pretreatment has been shown to prevent premature luteolysis in corpora lutea induced by GnRH treatment (McLeod et al., 1982; Hunter et al., 1986; Southee et al., 1988a). Pretreatment with progesterone reduces the endogenous pulsatile secretion of $\mathrm{PGF}_{2 u}$ in GnRH-treated ewes (Hunter et al., 1989), and the oxytocin-induced PGFM release in post partum cows (Zollers et al., 1989). The lack of a response to oxytocin in the group pretreated with progesterone in this study confirms this result in ewes. The ability of progesterone pretreatment to decrease the number of oxytocin receptors during the early luteal phase in ewes (Hunter et al., 1989) and cows (Zollers et al., 1993) is probably the cause of the attenuation in the secretion of $\mathrm{PGF}_{2 u^{\prime}}$ and, therefore, the prevention of premature luteolysis.

In Expt 2, a physiological dose of oxytocin administered on day 4 evoked a PGFM response in $29 \%$ of the ewes not pretreated with progesterone. In ewes that displayed abnormal luteal function in the present study, the PGFM concentrations measured following oxytocin administration were approximately $130 \%$ of baseline concentrations. Zollers et al. (1989) used a large dose of oxytocin (100 iu) to investigate the uterine PGFM response in post partum cows exhibiting normal and abnormal luteal function. Oxytocin caused an increase in PGFM concentrations in cows not pretreated with progesterone (abnormal) on day 5 which was equal in magnitude to that seen in progesterone pretreated (normal) cows on day 16 . Therefore, in both ewes and cows an oxytocin challenge administered during the early luteal phase of a short oestrous cycle evokes an increase in PGFM concentrations similar to that seen following oxytocin administration during the late luteal phase of a normal cycle. Furthermore, in all cases, the PGFM response to oxytocin was apparent before a decrease in progesterone was detected (see results above and Zollers et al., 1989; Silvia ef al., 1992). This indicates that the attainment of the prostaglandin response to oxytocin is a critical regulatory event which initiates the pulsatile secretion of $\mathrm{PGF}_{2 \alpha}$ during premature and normal luteolysis.

In conclusion, continuous oxytocin administration at about the time of ovulation does not prevent premature luteal regression, probably because oxytocin fails to downregulate existing oxytocin receptors. A transient increase in progesterone concentrations around the time of ovulation is associated with the prevention of premature luteal regression. The luteal response to an extended exposure to progesterone around the same period was unclear as luteinization did not appear to take place. This study has demonstrated that pretreatment with progesterone is associated with a decrease in the uterine PGFM response to oxytocin, and provides further evidence that premature luteolysis occurs owing to an increased number of functional oxytocin receptors during the early luteal phase.

A. P. Beard was in receipt of a MAFF postgraduate scholarship. We thank the staff of JABU for their help with the animal work and J. Craigon for statistical advice.

\section{References}

Asher GW, Peterson AJ and Duganzich D (1989) Adrenal and ovarian sources of progesterone secretion in young female fallow deer, Dama dama. Journal of Reproduction and Fertility $\mathbf{8 5} 667-675$

Beard AP and Hunter MG (1994a) Effects of progesterone pretreatment on the oxytocin receptor concentration and the response to oxytocin during the simulated early luteal phase in the ovariectomized ewe Journal of Reproduction and Fertility 102 57-63

Beard AP and Hunter MG (1994b) Effects of bovine follicular fluid and exogenous oestradiol on the $\mathrm{GnRH}$-induced short luteal phase in anoestrous ewes Journal of Reproduction and Fertility 100 211-217

Beard AP, Hunter MG and Lamming GE (1994) Quantitative control of oxytocin induced uterine prostaglandin $\mathrm{F}_{2 u}$ release by progesterone and oestradiol in the ewe Journal of Reproduction and Fertility 100 143-150

Bray AR, Hecker JF and Wodzicka-Tomaszewska M (1976) Role of progesterone in regulating the length of the oestrous cycle in sheep Journal of Reproduction and Fertility $46522-523$

Cooper C, Evans ACO, Cook S and Rawlings NC (1995) Cortisol, progesterone and $\beta$-endorphin response to stress in calves Canadian Joumal of Animal Science 75 197-201

Cumming IA, Buckmaster JM, Blockey MA, Goding JR, Winfield CG and Baxter RW (1973) Constancy of interval between luteinizing hormone release and ovulation in the ewe Biology of Reproduction 9 24-29

Dixon IW and Thwaites CJ (1973) The effects of a single injection of progesterone on oestrous cycle length in ewes Journal of Agricultural Science 80 525-527

Flint APF and Sheldrick EL (1985) Continuous infusion of oxytocin prevents induction of uterine oxytocin receptor and blocks luteal regression in cyclic ewes Journal of Reproduction and Fertility 75 623-631

Homanics GE and Silvia WJ (1988) Effects of progesterone and estradiol-17 $\beta$ on uterine secretion of prostaglandin $F_{2 a}$ in response to oxytocin in ovariectomized ewes Biology of Reproduction $\mathbf{3 8} 804-811$

Hunter MG (1991) Characteristics and causes of the inadequate corpus luteum Journal of Reproduction and Fertility Supplement 43 91-99

Hunter MG, Southee JA, McLeod BJ and Haresign W (1986) Progesterone pretreatment has a direct effect on $\mathrm{GnRH}$-induced preovulatory follicles to determine their ability to develop into normal corpora lutea in anoestrous ewes Journal of Reproduction and Fertility 76 349-363

Hunter MG, Southee JA and Lamming GE (1988) Function of abnormal corpora lutea in vitro after $\mathrm{GnRH}$-induced ovulation in the anoestrous ewe Journal of Reproduction and Fertility 84 139-148

Hunter MG, Ayad VJ, Gilbert CL, Southee JA and Wathes DC (1989) Role of prostaglandin $\mathrm{F}_{2 i t}$ and oxytocin in the regression of $\mathrm{GnRH}$-induced abnormal corpora lutea in anoestrous ewes Journal of Reproduction and Fertility $\mathbf{8 5}$ $551-561$ 
Kaker ML, Murray RD and Dobson H (1984) Plasma hormone changes in cows during induced or spontaneous calvings and the early post partum period Veterinary Record 115 378-382

Lamming GE, Wathes DC and Peters AR (1981) Endocrine patterns of the post-partum cow Journal of Reproduction and Fertility Supplement 30 155-170

Lau TM, Gow CB and Fairclough RJ (1992) Differential effects of progesterone treatment on the oxytocin-induced prostaglandin $\mathrm{F}_{2 a}$ response and the levels of endometrial oxytocin receptors in ovariectomized ewes Biology of Reproduction 46 17-22

Lowry SR (1992) Use and misuse of multiple comparisons in animal experiments Journal of Animal Science 70 1971-1977

McLeod BJ and Haresign W (1984) Evidence that progesterone may influence subsequent luteal function in the ewe by modulating preovulatory follicle development Journal of Reproduction and Fertility 71 381-386

McLeod BJ, Haresign W and Lamming GE (1982) Response of seasonally anoestrous ewes to small-dose multiple injections of GnRH with and without progesterone pretreatment Joumal of Reproduction and Fertility 65 223-230

Ottobre JS, Lewis GS, Thayne WV and Inskeep EK (1980) Mechanism by which progesterone shortens the estrous cycle of the ewe Biology of Reproduction 23 1046-1053

Sheldrick EL and Flint APF (1986) Transient uterine refractoriness after oxytocin administration in ewes Journal of Reproduction and Fertility 77 523-529

Sheldrick EL and Flint APF (1990) Effect of continuous infusion of oxytocin on prostaglandin $\mathrm{F}_{2 \alpha}$ secretion and luteolysis in the cyclic ewe Reproduction, Fertility and Development 2 89-99
Silvia WJ, Randall RE, Aldrich SL and Hayes SH (1992) Uterine secretion of prostaglandin $\mathrm{F}_{2 a}$ in response to oxytocin in ewes: changes during the estrous cycle and early pregnancy Biology of Reproduction 46 1007-1015

Southee JA, Hunter MG and Haresign W (1988a) Function of abnormal corpora lutea in vivo after $\mathrm{GnRH}$-induced ovulation in the anoestrous ewe Journal of Reproduction and Fertility 84 13I-137

Southee JA, Hunter MG, Law AS and Haresign W (1988b) Effect of hysterectomy on the short life-cycle corpus luteum produced after GnRH-induced ovulation in the anoestrous ewe Journal of Reproduction and Fertility $\mathbf{8 4}$ 149-155

Wathes DC, Guldenaar SEF, Swann RW, Webb R, Porter DG and Pickering BT (1986) A combined radioimmunoassay and immunocytochemical study of ovarian oxytocin production during the periovulatory period in the ewe Journal of Reproduction and Fertility $\mathbf{7 8} \cdot 167-183$

Yuthasastrakosol P, Palmer WM and Howland BE (1975) Luteinizing hormone, oestrogen and progesterone levels in peripheral serum of anoestrous and cyclic ewes as determined by radioimmunoassay Journal of Reproduction and Fertility 43 57-65

Zollers WG, Garverick HA and Smith MF (1989) Oxytocin-induced release of prostaglandin $\mathrm{F}_{2 \alpha}$ in postpartum beef cows: comparison of short versus normal luteal phases Biology of Reproduction 41 262-267

Zollers WG, Garverick HA, Smith MF, Moffatt RJ, Salfen BE and Youngquist RS (1993) Concentrations of progesterone and oxytocin receptors in endometrium of postpartum cows expected to have a short or normal oestrous cycle Journal of Reproduction and Fertility 97 329-337 